\title{
Nutrient Composition of Sweetpotato Storage Roots Altered by Frequency of Nutrient Solution Change
}

\author{
P.J. Grant ${ }^{1}$ and J.Y. $\mathbf{L u}^{2}$ \\ Food Science, Tuskegee University, Tuskegee, AL 36088
}

\author{
D.G. Mortley ${ }^{3}$, P.A. Loretan ${ }^{2}$, C.K. Bonsi ${ }^{2}$, and W.A. Hill ${ }^{2}$ \\ George Washington Carver Agricultural Experiment Station, Tuskegee \\ University, Tuskegee, AL 36088
}

Additional index words. hydroponics, Ipomoea batatas, nutrient film system

\begin{abstract}
The sweetpotato [Ipomoea batatas (L.) Lam] breeding clone TU-82-155 was grown during Spring 1990 and Summer 1991 in standard Tuskegee Univ. (Alabama) growth channels $(0.15 \times 0.15 \times 1.2 \mathrm{~m})$ for 120 days in a greenhouse using a hydroponic (nutrient film) system with a modified half-strength Hoagland nutrient solution. The nutrient solution was changed every 2,14 , or 28 days. Total N, oil, ash, amino acid, vitamin, and mineral concentrations in storage roots generally were higher and dry weight and starch concentration were lower with 2 -day solution changes than with those less frequent.
\end{abstract}

Sweetpotato is an important root crop grown extensively in the southern United States. Nutrient film (NF) systems have been used successfully to grow various vegetables (Nicholls, 1977). These closed hydroponic systems involve recirculating a thin film of nutrient solution over the roots of plants growing in channels or pipes (Collins and Jensen, 1983). Storage root fresh and dry weights of sweetpotatoes (TU-82-155) grown in modified half-strength Hoagland solution (Hoagland and Amen, 1950) with biweekly solution changes were similar to or higher than those of field-grown plants -(Hill et al., 1992). The sweetpotato is one of eight crops selected by the National Aeronautics and Space Administration for study in closed ecological lifesupport systems (Tibbitts and Alford, 1982). Progress and problems associated with growing plants in controlled environments for fu-

\footnotetext{
Received for publication 7 July 1992. Accepted for publication 11 Mar. 1993. Contribution of the George Washington Carver Agricultural Experiment Station.This research was supported by funds from the National Aeronautics and Space Administration (Grant NAG1O-OO24) and U.S. Dept. of Agriculture/Cooperative State Research Service (Grant ALX-SP-1). The cost of publishing this paper was defrayed in part by the payment of page charges. Under postal regulations, this paper therefore must be hereby marked advertisement solely to indicate this fact.

'Research Specialist.

${ }^{2}$ Professor.
}

${ }^{3}$ Assistant Professor. ture space missions were reported (Langhans and Dreeson, 1988). Recent research with sweetpotato using NF systems has shown that TU-82-155 and 'Georgia Jet' were able to grow and develop storage roots (Hill et al., 1989; Loretan et rd., 1989; Mortley et al., 1991).

The main component of sweetpotato storage root dry weight is starch. Sweetpotato roots also contain substantial concentrations of carotenes (orange-flesh cultivars); vitamins B 1 (thiamine), B2 (riboflavin), and C (ascorbic acid); and minerals $\mathrm{K}, \mathrm{Ca}, \mathrm{P}$, and $\mathrm{Mg}$. Nutrient composition of sweetpotato storage roots may vary due to production practices, environmental conditions, and genetic factors (Collins and Walter, 1985). Nutrients such as $\mathrm{N}$ and $\mathrm{K}$ in nutrient solution become low 30 days after planting (D.G. Mortley, personal communication). We theorized that, if nutrients were supplied more frequently than biweekly, the nutrient composition of storage roots may increase, To our knowledge, there is no information on the influence of frequency of nutrient solution change (SC) on storage root nutrient composition of sweetpotatoes grown hydroponically or on how frequently nutrient solutions should be changed to improve root nutrient composition. Resh (1981) suggested that in a closed NF system, the nutrient solution should be changed every 2 to 3 weeks, depending on season and plant growth stage. Our objective was to determine the effect of frequency of nutrient SC on nutrient composition of sweetpotato storage roots.
The sweetpotato breeding clone TU-82155, developed at the George Washington Carver Agricultural Experiment Station, Tuskegee Univ. (TU), Tuskegee, Ala., was grown in an NF system (Hill et al., 1989; Loretan et al., 1989) using standard TU growth channels $(0.15 \times 0.15 \times 1.2 \mathrm{~m})$. Four vine cuttings $(15 \mathrm{~cm}$ long) were placed $25 \mathrm{~cm}$ apart in each channel supported by a flat pressureplate assembly (Morris et al., 1989). A modified $(1 \mathrm{~N}: 2.4 \mathrm{~K})$ half-strength Hoagland nutrient solution (Table 1) was circulated at 1 liter-min ${ }^{-1}$. Previous work showed that fullstrength Hoagland solution produced excess foliage and few enlarged storage roots, while half-strength solution produced the highest root yields (Morris et al., 1989). The concentration we used was (in milligrams per liter) $49 \mathrm{~N}-16 \mathrm{P}-1$ 17K-80Ca-24Mg-32S. All plants were cultured identically for the first 30 days, after which treatments were initiated. Treatments consisted of a nutrient SC every 2,14 , or 28 days. Nutrient solution $\mathrm{pH}$ was maintained between 5.5 and 6.0 by adding dilute $\mathrm{NaOH}$ or $\mathrm{HC} 1$. Solution electrical conductivity ranged between 0.3 and $1.8 \mathrm{dS} \cdot \mathrm{m}^{-1}$. Average day/ night photosynthetic photon flux and temperature were $447 / 119 \mu \mathrm{mol} \cdot \mathrm{m}^{-2} \cdot \mathrm{s}^{-1}$ and $28 / 22 \mathrm{C}$ for spring and $469 / 82 \mu \mathrm{mol} \cdot \mathrm{m}^{-2} \cdot \mathrm{s}^{-1}$ and $26 / 24 \mathrm{C}$ for summer. Each treatment, consisting of one channel containing four plants per treatment, was replicated four times in a completely randomized design. The experiment was conducted twice-in Spring 1990 and Summer 1991.

Plants were harvested 120 days after planting. Six storage roots between 213 and $352 \mathrm{~g}$ and four roots between 270 and $419 \mathrm{~g}$ from each treatment were collected and combined from spring- and summer-grown plants, respectively. The storage roots were peeled, sliced, and mixed uniformly for nutrient analy-

Table 1. Composition of modified half-strength Hoagland nutrient solution.

\begin{tabular}{lc}
\hline Solution composition & Concn \\
\hline Stock solution & (ml.liter $\mathrm{r}^{-1}$ ) \\
$1 \mathrm{M} \mathrm{CaCl}_{2}$ & 2.0 \\
$1 \mathrm{M} \mathrm{NH}_{4} \mathrm{H}_{2} \mathrm{PO}_{4}$ & 0.5 \\
$1 \mathrm{M} \mathrm{KNO}_{3}$ & 3.0 \\
$1 \mathrm{M} \mathrm{MgSO}_{4}$ & 1.0 \\
Solution A & 0.5 \\
Solution B & 0.5 \\
Trace-element stock solution & \\
Solution A & $(\mathrm{g} \cdot$ liter-1) \\
$\mathrm{H}_{3} \mathrm{BO}_{3}$ & 2.86 \\
$\mathrm{MnCl}_{2} \cdot 4 \mathrm{H}_{2} \mathrm{O}$ & 1.81 \\
$\mathrm{ZnSO}_{4} \cdot 7 \mathrm{H}_{2} \mathrm{O}$ & 0.22 \\
$\mathrm{CuSO}_{4} \cdot 5 \mathrm{H}_{2} \mathrm{O}$ & 0.08 \\
$\mathrm{MoO}_{3}$ & 0.09 \\
Solution B & $(\mathrm{g} \cdot \mathrm{liter}$ \\
EDTA ferric & 5.0 \\
\hline
\end{tabular}


sis. Dry weight, total $\mathrm{N}$ (TN), oil, and ash concentrations were determined according to the Association of Official Analytical Chemists (AOAC, 1985). Starch, total carotenes, and vitamins B1, B2, and C concentrations were determined as reported by Luet al. (1989). For amino acid analysis, a composite sample was prepared from six and four sweetpotato roots from each treatment of spring- and summer-grownplants, respectively. The roots were peeled, sliced, combined, dehydrated in an oven at $60 \mathrm{C}$, and ground into flour using a $0.180-\mathrm{mm}$ (60-mesh) sieve. The ground samples were analyzed by Medallion Laboratories, Minneapolis, using an amino acid analyzer. Potassium, $\mathrm{Na}, \mathrm{Ca}$, and $\mathrm{Mg}$ concentrations were determined by atomic absorption spectrophotometry. Phosphorus concentration was determined colonmetrically (Osbourne and Voogt, 1978).

Frequency of nutrient SC affected the nutrient composition of sweetpotato storage roots (Table 2). Dry weight was lower in both seasons with 2- than with 14- or 28-day SCs. Starch concentration was lower with 2- than with 14- or 28-day SCs in spring or with 14day SCs in summer. The lower starch concentration and dry weight of roots with 2-day SCs compared to those with 14- or 28-day SCs could be due to differences in growth stage. We observed that leaves with 2-day SCs were larger and seemed to be more succulent than those with less frequent SCs. Thus, the roots with 2-day SCs probably were in an early developmental stage, at a higher metabolic rate, absorbing more nutrients, but accumulating less starch compared to those with 14- or 28-day SCs. TN and amino acid concentrations were higher (Table 2) with 2- than with 14- or 28-day SCs (Table 3). The high TN could be due in part to the increased $\mathrm{N}$ available to plants with 2-day SCs compared to those with 14- or 28-day SCs. Root TN concentration was higher than total amino $\mathrm{N}$ computed from amino acid composition (Table 3). The difference could be due to inorganic N, since sweetpotatoes contain substantial nonprotein N (Purcell and Walter, 1980). For instance, 2-day SCs resulted in a higher $\mathrm{NH}_{3}$ concentration than 14- or 28-day SCs (Table 3 ). Protein content of sweetpotatoes generally ranges between $3 \%$ and $10 \%$ and is affected by cultivar, growing conditions, and plant growth stage (Austin et al., 1971; Li, 1974, Purcell et al., 1974). Sweetpotato protein is deficient in certain essential amino acids, and amino acid composition varies with cultivar. For instance, methionine and lysine concentrations in TU82-155 roots were lower than those in 'Jewel' (Purcell and Walter, 1982).

Root oil concentration was higher with 2than with 14- or 28-day SCs during Spring 1990, but was not different during Summer 1991 (Table 2). Ash is a key food component and consists mostly of cation oxides such as $\mathrm{K}$, $\mathrm{Na}, \mathrm{Ca}, \mathrm{Mg}, \mathrm{Fe}$, and Mn (Aurand et al., 1987). High ash means high mineral concentrations. Ash concentration was highest with 2- and least with 28-day SCs in both seasons (Table 2 ). This result agreed with those of the mineral analysis in Table 4.

Table 2. Nutrient composition of sweetpotato storage roots with 2, 14, or 28 days between nutrient solution change.

\begin{tabular}{|c|c|c|c|c|c|c|}
\hline \multirow{2}{*}{$\begin{array}{l}\text { Frequency } \\
\text { of change } \\
\text { (days) }\end{array}$} & \multirow[b]{2}{*}{$\begin{array}{c}\text { Dry } \\
\text { wt }(\%)\end{array}$} & \multicolumn{5}{|c|}{ Dry wt (\%) } \\
\hline & & Starch & $\begin{array}{c}\text { Total } \\
\mathrm{N}\end{array}$ & $\begin{array}{c}\text { Amino } \\
\mathrm{N}\end{array}$ & Oil & Ash \\
\hline \multicolumn{7}{|c|}{ Spring 1990} \\
\hline 2 & 15.5 & 39.9 & 2.58 & 0.072 & 5.60 & 6.64 \\
\hline 14 & 18.6 & 53.8 & 1.19 & 0.035 & 2.78 & 5.59 \\
\hline 28 & 20.7 & 52.7 & 0.79 & 0.019 & 1.11 & 3.24 \\
\hline $\operatorname{LSD}(0.05)$ & 2.06 & 5.12 & 0.74 & 0.022 & 2.62 & 1.63 \\
\hline \multicolumn{7}{|c|}{ Summer 1991} \\
\hline 2 & 13.5 & 43.8 & 2.76 & 0.091 & 1.09 & 10.24 \\
\hline 14 & 18.0 & 63.0 & 1.31 & 0.044 & 0.79 & 5.16 \\
\hline 28 & 20.0 & 53.3 & 0.89 & 0.033 & 0.79 & 4.20 \\
\hline $\operatorname{LSD}(0.05)$ & 2.94 & 11.11 & 0.36 & 0.029 & 1.02 & 1.16 \\
\hline
\end{tabular}

Table 3. Amino acid concentration of sweetpotato storage roots with 2 , 14, or 28 days between nutrient solution change. ${ }^{2}$

\begin{tabular}{|c|c|c|c|c|c|c|}
\hline \multirow{3}{*}{$\begin{array}{l}\text { Amino } \\
\text { acid }^{y} \\
\end{array}$} & \multicolumn{3}{|c|}{ spring 1990} & \multicolumn{3}{|c|}{ Summer 1991} \\
\hline & \multicolumn{6}{|c|}{ Frequency of change (days) } \\
\hline & 2 & 14 & 28 & 2 & 14 & 28 \\
\hline \multicolumn{7}{|c|}{ Dry wt (\%) } \\
\hline Asp & 3.05 & 1.27 & 0.53 & 3.81 & 1.44 & 0.70 \\
\hline Thr & 0.52 & 0.23 & 0.12 & 0.41 & 0.24 & 0.19 \\
\hline Ser & 0.60 & 0.24 & 0.11 & 0.65 & 0.29 & 0.21 \\
\hline Glu & 0.93 & 0.51 & 0.33 & 1.23 & 0.69 & 0.40 \\
\hline Pro & 0.30 & 0.19 & 0.14 & 0.72 & 0.40 & 0.14 \\
\hline Gly & 0.36 & 0.20 & 0.18 & 0.44 & 0.28 & 0.70 \\
\hline Ala & 0.76 & 0.43 & 0.23 & 0.74 & 0.35 & 0.23 \\
\hline Val & 0.51 & 0.33 & 0.16 & 0.61 & 0.30 & 0.23 \\
\hline Met & 0.13 & 0.07 & 0.04 & 0.23 & 0.09 & 0.08 \\
\hline Ile & 0.33 & 0.18 & 0.11 & 0.44 & 0.18 & 0.16 \\
\hline Leu & 0.34 & 0.18 & 0.11 & 0.62 & 0.32 & 0.24 \\
\hline Tyr & 0.22 & 0.11 & 0.07 & 0.16 & 0.15 & 0.11 \\
\hline Phe & 0.43 & 0.21 & 0.14 & 0.49 & 0.29 & 0.21 \\
\hline His & 0.14 & 0.05 & 0.05 & 0.21 & 0.10 & 0.05 \\
\hline Lys & 0.20 & 0.12 & 0.08 & 0.29 & 0.14 & 0.05 \\
\hline Arg & 0.29 & 0.14 & 0.06 & 0.41 & 0.23 & 0.12 \\
\hline $\mathrm{NH}_{3}$ & 0.30 & 0.13 & 0.05 & 0.49 & 0.23 & 0.12 \\
\hline Total $^{x}$ & 9.11 & 4.46 & 2.46 & 11.46 & 5.49 & 3.82 \\
\hline
\end{tabular}

${ }^{2}$ Mean values were for composite samples from six and four roots from each of four replications per treatment for spring- and summer-gown plants, respectively.

${ }^{y}$ Asp = aspartic acid, Thr = threonine, Ser = serine, Glu = glutamic acid, Pro = proline, Gly = glycine, Ala $=$ alanine, $\mathrm{Val}=$ valine, Met $=$ methionine, $\mathrm{Ile}=$ isoleucine, $\mathrm{Leu}=$ leucine, $\mathrm{Tyr}=$ tyrosine, $\mathrm{Phe}=$ phenylalanine, His= histidine, Lys = lysine, $\operatorname{Arg}=$ arginine, and $\mathrm{NH}_{3}=$ ammonia.

${ }^{x}$ Total does not include $\mathrm{NH}_{3}$.

Table 4. Vitamin and mineral concentration of sweetpotato storage roots with 2,14 , or 28 days between nutrient solution change.

\begin{tabular}{|c|c|c|c|c|c|c|c|c|c|}
\hline \multirow{3}{*}{$\begin{array}{l}\text { Frequency } \\
\text { of change } \\
\text { (days) }\end{array}$} & \multirow[b]{2}{*}{$\mathrm{P}$} & \multirow[b]{2}{*}{$\mathrm{K}$} & \multirow[b]{2}{*}{$\mathrm{Na}$} & \multirow[b]{2}{*}{$\mathrm{Ca}$} & \multirow[b]{2}{*}{$\mathrm{Mg}$} & \multicolumn{4}{|c|}{ Vitamins } \\
\hline & & & & & & Carotenes & $\mathrm{C}$ & $\mathrm{B}$ & B2 \\
\hline & \multicolumn{5}{|c|}{ (\% dry wt) } & \multicolumn{3}{|c|}{$(\mathrm{mg} / 100 \mathrm{~g}$ dry wt $)$} & $(\mu \mathrm{g} / 100 \mathrm{~g})$ \\
\hline \multicolumn{10}{|l|}{ Spring 1990} \\
\hline 2 & 1.68 & 4.01 & 0.15 & 0.24 & 0.24 & & & & \\
\hline 14 & 0.91 & 3.09 & 0.12 & 0.12 & 0.14 & & & & \\
\hline 28 & 0.77 & 1.55 & 0.08 & 0.16 & 0.12 & & & & \\
\hline LSD $(0.05)$ & 0.27 & 0.82 & 0.04 & 0.07 & 0.08 & & & & \\
\hline \multicolumn{10}{|c|}{ Summer 1991} \\
\hline 2 & 2.71 & 4.80 & 0.16 & 0.99 & 0.41 & 52 & 113 & 1.44 & 6.38 \\
\hline 14 & 1.23 & 1.98 & 0.23 & 0.28 & 0.11 & 49 & 96 & 1.36 & 4.72 \\
\hline 28 & 1.13 & 1.59 & 0.08 & 0.16 & 0.07 & 40 & 109 & 0.66 & 2.68 \\
\hline $\operatorname{LSD}(0.05)$ & 0.35 & 1.97 & 0.11 & 0.32 & 0.19 & 19 & 39 & 0.28 & 2.99 \\
\hline
\end{tabular}

Sweetpotatoes can be a rich source of carotenes (provitamin A) and vitamin $\mathrm{C}$ ( $\mathrm{Lu}$ et al., 1989), concentrations of which were unaffected by SC frequency (Table 4). The higher concentrations of vitamins B1 and B2 with 2than with 28-day SCs (determined only for summer-grown plants, Table 4) may reflect the influence of SC frequency on the metabolic rate and developmental stage of storage roots, since these vitamins are cofactors for enzymes involved in carbohydrate metabolism (Lehninger, 1982).

Roots grown with 2-day SCs had higher concentrations of $\mathrm{P}, \mathrm{K}, \mathrm{Na}, \mathrm{Ca}$, and $\mathrm{Mg}$ than those grown with 14- or 28-day SCs (Table 4). This pattern would be expected since increased SC frequency increased the concentration of available nutrients. If the metabolic rate of 
plants grown with 2-day SCs had been higher than that with 14- or 28-day SCs, then the mineral requirement might have been higher.

Our results indicated that the nutrient composition of sweetpotato storage roots grown in NF systems generally were similar to that of field-grown roots (Hill et al., 1989). With the exception of starch, the concentrations of $\mathrm{TN}$, oil, ash, amino acids, and vitamins B 1 and B2 generally were higher in roots grown with 2day SCs than in those grown with less frequent (14- or 28-day) SCs. This trend was observed regardless of season. We conclude that the nutrient value of hydroponically grown sweetpotato roots was increased by increasing $\mathrm{SC}$ frequency.

\section{Literature Cited}

Association of Official Analytical Chemists. 1985 Official methods of analysis. 14th ed. Assn. Offic. Anal. Chemists, Washington, D.C.

Aurand, L.W., A.E. Woods, and M.R. Wells. 1987. Food composition and analysis. Van Nostrand Reinhold Co., New York. p. 33-34.

Austin, M.E., L.H. Hung, and B. Graves. 1971. Some observations on the growth and development of sweetpotatoes. J. Hort. Sci. 45:257264.

Collins, W.L. and M.H. Jensen. 1983. A 1983 repor on the current status and long term interdisciplinary needs for research on hydroponics. Environ. Res. Lab., Univ. of Arizona, Tucson.
Collins, W.W. and W.M. Walter. 1985. Fresh roots for human consumption, p. 153-173. In: J.C. Bouwkamp (ed.). Sweetpotato products: A natural resource for the tropics. CRC Press, Boca Raton, Fla.

Hill, W.A., P.A. Loretan, C.K. Bonsi, C.E. Morns, J.Y. Lu, and C. Ogbuehi. 1989. Utilization of sweetpotatoes in CELSS. Adv. Space Res.9:2941.

Hill, W.A., D.G. Mortley, C.L. MacKowiak, P.A Loretan, T.W. Tibbitts, R.M. Wheeler, C.K. Bonsi, and C.E. Morns. 1992. Growing root and tuber crops hydroponically. Adv. Space Res. 12:125-131.

Hoagland, D.R. and D.L. Arnon. 1950. The waterculture method for growing plants without soil. Calif. Agr. Expt. Sta. Circ. 347.

Langhans, R.W. and D.R. Dreeson. 1988. Challenges to plant growing in space. HortScience 23:286-293.

Lehninger, A.L. 1982. Principles of biochemistry. Worth Publishers, New York. p. 683-686.

Li, L.L. 1974. Variation in protein content and its relation to other characters in sweetpotatoes. J. Agr. Assn. China. p. 88:17.

Loretan, P.A., C.K. Bonsi, W.A. Hill, C.R. Ogbuehi, D.G. Mortley, J.Y. Lu, C.E. Morns, and R.D. Pace. 1989. Sweetpotato growth parameters, yield components and nutritive value for CELSS applications. J. Aerospace 98:1090-1094.

Lu, J. Y., P. Miller, and P.A. Loretan. 1989. Gamma radiation dose rate and sweetpotato quality. J. Food Quality 12:369-376.

Morris, C. E., P.A. Loretan, C.K. Bonsi, and W.A. Hill. 1989. Moveable root contact-pressure plate assembly for hydroponic system, U.S. Patent 8,860,490,29 Aug. 1989

Mortley, D. G., C.K. Bonsi, P.A. Loretan, W.A. Hill, and C. Ogbuehi. 1991. Evaluation of sweetpotato genotypes for adaptability to hydroponic systems. Crop Sci. 31:845-847.

Nicholls, R.E. 1977. Beginning hydroponic soilless gardening: The beginners guide to growing vegetables, houseplants, flowers and herbs without soil. Running Press, Philadelphia.

Osbourne, D.R. and P. Voogt. 1978. The analysis of nutrients in food. Academic, New York.

Purcell, A.E., H.E. Swaisgold, and D.H. Pope 1974. Protein and amino acid content of sweetpotato cultivars. J. Amer. Soc. Hort. Sci. 97:30-33.

Purcell, A.E. and W.M. Walter. 1980. Changes in composition of the NPN fraction of 'Jewel' sweetpotatoes during storage. J. Agr. Food Chem. 28:842-844.

Purcell, A.E. and W.M. Walter. 1982. Stability of amino acids during cooking and processing of sweet potatoes. J. Agr. Food Chem. 30:443444.

Resh, H.M. 1981. Hydroponic food production: A definitive guide book for the advanced home gardener and the commercial hydroponic grower. Woodridge Press Publishing Co., Santa Barbara, Calif.

Tibbitts, T. W. and K.K. Alford. 1982. Controlled ecological life support systems-Use of higher plants: Proc. Natl. Aeronautics and Space Administration (NASA) Workshops, Chicago, Nov. 1979, and Moffett Field, Calif., Mar. 1980. NASA Sci. and Tech. Info. Branch, Washington, D.C. 